YEARBOOK

of ANTITRUST

and REGULATORY

STUDIES

www.yars.wz.uw.edu.pl
Peer-reviewed scientific periodical, focusing on legal and economic issues of antitrust and regulation. Creative Commons Attribution-No Derivative Works 3.0 Poland License.

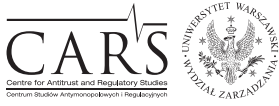

Centre for Antitrust and Regulatory Studies, University of Warsaw, Faculty of Management www.cars.wZ.uw.edu.pl

\title{
So Close, So Different - Regional Rail Transport in Poland, the Czech Republic and Slovakia
}

\author{
by \\ Marcin Król*, Jakub Taczanowski*
}

\section{CONTENTS $^{* * * *}$}

I. Introduction

II. Historical, spatial and socio-economic context

III. Poland, the Czech Republic, Slovakia: the three models. Experiences and results

1. Poland

2. The Czech Republic

3. Slovakia

IV. Conclusions

\section{Abstract}

The objective of this paper is to present three different models of regional railway passenger transport that emerged in the process of post-communist transition after 1989 in neighbouring countries: Poland, the Czech Republic and Slovakia. After an introduction, the second section of the paper shows the historical, spatial and socio-economic context of the analysis. The three resulting models are presented in the following section. This part of the paper is also devoted to the discussion of the developments, experiences and results obtained in Poland, the Czech Republic and Slovakia. The final section provides conclusions.

* Dr. Marcin Król, Collegium of World Economy, Warsaw School of Economics; mkrol2@ sgh.waw.pl.

** Dr. Jakub Taczanowski, Institute of Geography and Spatial Management, Jagiellonian University in Cracow, jakub.taczanowski@poczta.onet.pl.

*** Article received: 20 July 2016; accepted: 2 October 2016.

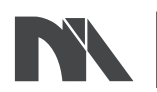

Ministry of Science and Higher Education

Republic of Poland
The creation of the English-language version of these publications is financed in the framework of contract No. 768/P-DUN/2016 by the Ministry of Science and Higher Education committed to activities aimed at the promotion of education. 


\section{Résumé}

Lobjectif de cet article est de présenter trois modèles différents de transport ferroviaire commun au niveau régional qui sont apparus pendant le processus de transition post-communiste après 1989 dans les pays voisins: la Pologne, la République tchèque et la Slovaquie. Après l'introduction, l'article présente dans la deuxième section un contexte historique, spatial et socio-économique de l'analyse. Les trois modèles différents sont présentés dans la section suivante. Cette partie de l'article est aussi consacrée à la discussion des développements, des expériences et des résultats obtenus en Pologne, en République tchèque et en Slovaquie. La section finale présente des conclusions.

Key words: railway transport; regional transport; public service.

JEL: R40; R50; P50; L92

\section{Introduction}

Poland, the Czech Republic and Slovakia are neighbouring CentralEuropean countries. They have a common historical, social and cultural identity. As the aftermath of World War II, they fell together into the Soviet sphere of influence ${ }^{1}$. After the historic year of 1989, they simultaneously started post-communist transformation (also referred to as transition) towards capitalism and democracy. Fifteen years later, in 2004, they joined the European Union altogether.

So close to each other and alike, in many areas of the economy they have adopted surprisingly different transformation models. This can be seen very well on the example of regional passenger rail transport systems.

Regional passenger rail transport is a specific segment of the railway system. It meets societal needs for public transport at the lowest - local and regional levels. It has special attributes that have traditionally encouraged government involvement, in Europe and elsewhere. Railway infrastructure, itself, has economic characteristics, mostly related to so-called natural monopoly, that have attracted substantial regulation. Moreover, local railway networks are expensive to build and maintain and yet in regional passenger transport they are served at a relatively low intensity of traffic. This means that such transport services are per se non-profitable and would not be supplied without public intervention. In other words, they have the characteristics of public

1 Until 1993, when they split into two sovereign states, the Czech Republic and Slovakia existed as one country - Czechoslovakia. 
services. Governments choose to subsidize them due to both efficiency and equity considerations. On the one hand, regional public transport is seen as an important factor of local economic development. Often, it is considered to be an example of a so called merit good, creating positive and long-term benefits for society. On the other hand, providing universal access to a given level of infrastructure services, including regional passenger transport, is often viewed as an important element of ensuring equal opportunities for individual citizens. As J.A. Gómez-Ibáñez writes, "[i]nfrastructure may not be deemed as essential to development and equal opportunity as education or health, but it is often just behind" (Gómez-Ibáñez, 2003, p. 9).

Post-communist transformation of the economy has not been an easy task. When it comes to railway transport, this has been further complicated by the fact that the systemic change in Central-European countries was accompanied by a paradigm shift in Western economies concerning government involvement in network industries. However, the new model - with a fundamental change: liberalization of downstream markets - spread in the Western European railway sector (since the 90's) relatively slowly, with many hesitations and controversies, especially in public passenger transport including its regional branch. In the traditional model, public transport was provided by a monopolistic, vertically integrated railway undertaking with a so-called national carrier status. Public service was often cross-subsidized through a profitable business activity. It is worth noting that this paradigm did not differ significantly from the model used in pre-transition Poland and Czechoslovakia. The new model proposes to buy public transport services in a competitive market. No longer crosssubsidized, they should be subject to competitive bidding for a public service contract (which means competition for the market). Importantly, in the case of regional passenger transport, public services should be organized and financed at the regional level (by regional authorities) ${ }^{2}$.

However in practice, the new model has been so far fully adopted only in Great Britain and Sweden. On the other hand, some countries, such as France, have continued to persist with the traditional model based on a monopolistic national carrier. Other countries are somewhere in the middle between the two models. Thus, the shape of rail public passenger transport varies across European countries - including Central-European ones. This paper provides an overview of evidence on regional passenger rail transport in Poland, the Czech Republic and Slovakia.

2 Much has been written about what is referred here as "the new model" for the railway sector in Europe, or - in other words - about the European approach to liberalization and deregulation of railways. It is thus believed that there is no need to even briefly discuss this subject in this paper. A comprehensive look on this issue can be found e.g. in: Finger and Messulam, 2015. 


\section{Historical, spatial and socio-economic context}

The railway systems found in Poland, the Czech Republic and Slovakia were basically formed between mid $19^{\text {th }}$ century and World War I in different historical circumstances. What they all have in common is the fact that when their networks were being built, neither of these countries existed on the European map as an independent state. The territory of present day Czech Republic, Slovakia and South-Eastern Poland belonged to Austria-Hungary, Central-Eastern Poland was part of Russia and its North-Western provinces were under German rule. All three empires had their own economic and transport policies, and so railway networks developed in completely different ways on these territories. Poland illustrates this situation best with a very dense network of regional lines serving local industry and agriculture in the German controlled part and a poor system of military oriented straight trunk lines, which ignored many important towns, in the Russian partition. This situation changed in 1918 when - alongside the development of own national structures in Poland and Czechoslovakia - national railway networks were created and first investments were launched in order to reintegrate the three parts of Poland. Similar developments were observed in Czechoslovakia where the most urgent need was to connect Slovakia (which had been part of Hungary) with Moravia and Bohemia (which used to belong to Austria).

After World War II, both Poland and Czechoslovakia developed their transport systems according to the particular needs of centrally planned economies with their focus on heavy industry and military demands. National railway companies - PKP in Poland and ČSD in Czechoslovakia, fully controlled by the governments already since 1918/19 - obtained the legal monopoly on rail transport of passengers and goods. All private companies and those owned by local governments were nationalized. Giving priority to the requirements of an ineffective industry, irrational cooperation links among industrial plants and very long commuting distances resulted in a complete lack of balance between transport demand patterns as well as in the actual possibilities of the railway system to answer to the increasing transport needs (Kubáček, 2007, p. 178).

These factors were present both in Czechoslovakia and Poland but their influence and importance were somewhat different in these countries. It seems that there were three main reasons for this. First, the general economic structure of the country - mainly rural and agricultural in Poland (except ex-German territories and big cities) versus urbanized and industrialized in Czechoslovakia (especially in Bohemia and Moravia, not as much in Slovakia). The second factor was connected to the first and related to the character of 
the railway network. The differences between Poland's former partitions were very significant and some inter-regional connections (e.g. Warsaw-Wrocław) were still missing ${ }^{3}$. By contrast, Czechoslovakia (in particular, once again in Bohemia and Moravia) was characterized by a well-developed and integrated system, with many local lines that served almost all towns in the country. Finally, there was the third factor - the geopolitical one. Poland was situated on the main trunk line from Moscow to Berlin, which resulted in its importance for military and freight transit between the Soviet Union and East Germany. In fact, one of the first investments made after the reconstruction of train lines damaged during World War II in 1955 was the long Warsaw bypass designed for heavy freight trains down the East-West line (Skierniewice-Łuków). This does not mean that this problem did not exist in Czechoslovakia but its scale was less significant.

Many new investments were launched in Poland after 1945 because of its generally low scale of prior industrialization. The government preferred coal mining, metallurgy, the chemical industry as well as fossil-fuel electricity generation. Most new railway lines which were constructed in the socialist period were designed to serve these plants. The best examples are the bypass of Kraków via Nowa Huta (1952-55), the line Kielce - Tarnobrzeg (1973) and in particular the broad gauge Metallurgy-Sulfur Line (in Polish: Linia Hutniczo-Siarkowa) from the Soviet border to the largest steel mill in Poland, which also served new sulfur mines in the vicinity of Tarnobrzeg (1979) (Koziarski, 1993, p. 92). Even the most important railway investment made after 1945 - the Central Rail Line (in Polish: Centralna Magistrala Kolejowa) from Warsaw to Katowice (1977), today serving exclusively passenger traffic - was designed for heavy coal trains and started to be used by express trains only some years after its construction (Basiewicz, Łyżwa and Modras, 1977, p. 12). Also electrification -certainly one of the most significant achievements in the history of Polish railways - was freight-oriented, especially in its earlier days of the 1950s and 1960s s $^{4}$ Taylor, 2007, p. 92).

By contrast, Czechoslovakia could already in 1945 be described as an industrialized country, although the character of its industry was often quite different from the expectations of socialist planners. Nevertheless, the existing industrial and transport infrastructure was certainly well developed, and so it was more the case of adjusting existing infrastructure to the new socialist demands than building it from scratch. This is why the scale of rail investments

3 The direct line from Warsaw to Wrocław has not been built till recently although the section from Wrocław to the Prussian-Russian border near Wieruszów was constructed in 1871-72.

4 This situation changed completely during wide-scale electrification in the 1980s when many purely regional lines were modernized. 
in new lines was much smaller here than in Poland. In fact, only three longer sections were built, of which two in Slovakia: a broad gauge freight line from the Soviet border to the steel mill in Košice (1965) - similar to the Polish Metallurgy-Sulfur Line, and section Turňa nad Bodvou - Rožňava (1955), which constituted the last part of the so-called Southern Rail Line that connected Central and Eastern Slovakia (Kubáček, 2007, p. 194). The only important new line in the Czech part of the country was the section Brno - Havličkův Brod (1958) - part of the new connection between Prague and Brno (Schreier, 2010, p. 118). Furthermore, some new sections had to be built as pre-existing lines formed obstacles to mining activity - in particular, in the North Bohemian brown coal basin. It was electrification rather than the construction of new train lines that highlighted the industrial character of socialist Czechoslovak railways.

However, the differences between Poland and the Czech Republic seem to have been even more significant in regional transport. Poland can be described as a country where regional rail transport has always been quite underestimated and neglected. Factors listed above - regional disparities in the density of the network, primarily rural character of vast areas of the country, focus on new industrial and strategic needs - were clearly present. Moreover, a scattered settlement structure, typical for many parts of Poland, has always been unfavourable for regional railways development. This explains why little attention has been paid to this sector of rail services in socialist Poland. This became evident after the large-scale private motorization programme was launched by the government in the 1970s. The appearance of the first, relatively affordable Polish Fiats showed the poor state of the railways much clearer than before. The services of the PKP started to be perceived as rather unattractive, slow and unreliable (Jarząbek, 2012, p. 58).

In Czechoslovakia, by contrast, the important role of regional railway connections was maintained at least till the end of the communist era. Local rail services were characterised by relatively intense traffic and the usage of light railcars whereby Czechoslovakia had a long tradition in their manufacturing ${ }^{5}$ (Bittner, Křenek, Skála and Šrámek, 2010, p. 205). State railway policy on this issue was completely different from Poland, where heavy diesel locomotives produced for freight or intercity trains were used on local lines also. It is clear that the aforementioned spatial and economic factors facilitated the maintenance of the strong position of local rail services in Czechoslovakia. However, it cannot be sufficiently stressed how crucial the consistent and rational policy of the Czechoslovak State Railways was. In fact, when the transformation started in 1989, these different approaches in both

5 In 1948, albeit freight traffic had priority, a new railcar M131.1 was designed. Over 500 units were built in order to provide rational services and local lines. 
neighbouring countries quickly resulted in completely dissimilar development of its regional services.

\section{Poland, the Czech Republic, Slovakia: the three models. Experiences and results}

\section{Poland}

Although the transformation began in 1989, the Polish railway sector did not see too many real symptoms of the wind of change until 2001. The Railway Transport Act of $1997^{6}$ formally launched the liberalization process, and yet it had virtually no effects on the market situation. Instead, it was rather a step towards the implementation of acquis communitaire (Directive 91/440/EEC followed by Directives 95/18/EC and 95/19/EC) needed for Poland's accession to the EU. In 2001, however, as a result of the Act of 8 September 2000 on the Commercialization, Restructuring and Privatization of $\mathrm{PKP}^{7}$, the incumbent was divided into 24 smaller companies, creating a holding structure called the PKP Group. These newly-created companies included an infrastructure manager (PKP PLK) and several operator companies including PKP Przewozy Regionalne (Polish for Regional Services). PKP Przewozy Regionalne (hereinafter, PKP PR) was the incumbent company on the regional passenger rail market in Poland. The latter market - albeit still monopolistic - quickly became subject to devolutionary efforts of the government.

Organizing and subsidizing regional passenger rail services became part of the list of mandatory tasks and functions of local authorities as early as $2000^{8}$. Yet over the first three years, the subsidizing activity was carried out exclusively by means of a state budget grant given to regional authorities ${ }^{9}$. In practice, the grant turned out to be much lower than previously promised ${ }^{10}$. This had far-reaching consequences for regional transport. First-off, it was necessary to significantly reduce the number of trains run in the regions. As a result, over the years 2001-2003, the number of passengers and performance in regional

6 Journal of Laws 1997, No. 96, item 591.

7 Journal of Laws 2000, No. 84, item 948, as amended.

${ }^{8}$ Based on the above Act of 8 September 2000 on the Commercialization, Restructuring and Privatization of PKP.

9 Since 2004, regions were obliged to co-finance public rail transport. They were also given an instrument to do this. From then on, local authorities could keep more of what they collected as income taxes.

${ }^{10}$ Respectively, in $2001-2003,66 \%, 52 \%$ and $31 \%$ of what was previously agreed. 
traffic visibly dropped. This had important spatial consequences as several lines were closed for passenger services. In fact, the reduction of the Polish railway network ${ }^{11}$ continued in following years also. According to Komusiński (2010), over $500 \mathrm{~km}$ of lines were closed for passenger trains between 2003 and 2008. Furthermore, the insufficiency of the state budget grants contributed to the loss of financial stability and acute financial crisis of PKP PR, its only and final beneficiary. This, in turn, had significant repercussions for the sector in the coming years.

The new Railway Transport Act of $2003^{12}$ (together with a relevant implementing act ${ }^{13}$ ) confirmed the responsibility of regional governments for the provision of public services in rail transport in Poland. From then on, they had to be delivered on the basis of competitive bidding for public contracts. In theory, therefore, it was a courageous step in the right (or at least advised) direction - towards what was described in Section I of this paper as a new model of public services provision. In practice, however, barriers to entry were too high for new entrants and the incumbent PKP PR was bound to win the tenders.

The fundamental barrier stemmed from the short duration of a typical contract - 1-2 years in the initial period. Such duration was not long enough to justify the purchase of rolling stock - a crucial question for a company engaging in railway transport as a business, which every potential new entrant would be. This fundamental barrier naturally led to another. The short duration of contracts resulted in a short bidding and mobilization time. In case of an annual contract, it was usually only a few months. This meant that service provision had to begin almost immediately. It was another very serious barrier to entry for non-incumbent players that needed to order trains and to recruit staff first.

The combination of the above barriers was fatal for the development of a competitive market and made tenders a de facto fiction in Poland. The most important research question seems to be here: why did regional authorities decide for such a short duration of public concessions, with the consequence that they had to use the monopolistic incumbent and buy its expensive services? The possible answer is quite surprising.

Paradoxically, the main reason for this seems to be the aforementioned acute financial crisis of the incumbent PKP PR. The government decided to refrain from restructuring PKP PR and so the company was left alone.

11 A large-scale regression of the Polish railway network began immediately after the transformation. About $10 \%$ of the entire network was closed between 1988 and 1993 (Komusiński, 2010).

12 Journal of Laws 2003, No. 86, item 989, as amended.

13 Journal of Laws 2004, No. 95, item 953. 
Its increasing demand for regional subsidies could be clearly seen. Regional authorities feared that in case of concluding a contract for a longer duration, PKP PR would seek to renegotiate it continually to obtain more and more funds. Due to the underdevelopment of the market, it seemed fair to assume that even a tender for a longer than before contract could in many cases attract nobody but the incumbent. The contract would thus be awarded to the foregoing (incumbent) operator but for a longer duration. As a result, a regional government would be even more exposed to the opportunistic behaviour of the incumbent.

An attempt to change the status quo in search for an operator other than PKP PR might seem too risky. Announcing another tender for a short-term contract could thus be considered a reasonable choice of a lesser evil.

The government's devolutionary efforts gained momentum in 2008. PKP PR was passed on to regional governments. Surprisingly, it did not change too much. The term "PKP" was quickly removed from the name of the company, which since then began operating under the "PR" logo. There was no longer the need to continue the fiction of "unnecessary" tenders. The company was now technically regions-owned, which made it possible to award public contracts "in house", in accordance with EU and Polish law. Yet the relations between the regions and the incumbent operator did not change greatly.

Sixteen regional governments or shareholders, who were given the company against their will, did not consider it to be their own. In actuality, they did not have too much influence over the operator's actions. The stock ownership was too dispersed ${ }^{14}$. Moreover, due to demographic, spatial and socio-economic differences among individual regions, regional governments did not have a sense of common interests in the company. Lack of financial transparency and unclear settlement system added to the picture.

It was also not without significance that the largest shareholder - Mazovia did not use the services of PR. In order to avoid awkward cooperation with the incumbent company, Maziovia had created its own operator Koleje Mazowieckie (Polish for Mazovian Railways) as early as in 2004. It then awarded to that operator a direct (in house) concession for public rail transport in its own region. This model has been imitated by other regions and the mandatory "devolution" of PKP PR has not stopped this process. Region-owned railways have been also created by Lower Silesia (Koleje Dolnoślaskie, Polish for Lower Silesian Railways, operating since 2008), Silesia (Koleje Ślaskie, Polish for Silesian Railways, operating since 2011), Wielkopolska (Koleje Wielkopolskie, operating since 2011), Małopolska (Koleje Matopolskie, operating since 2014) and Lódzkie (Łódzka Kolej Aglomeracyjna, Polish for Agglomeration Railway

14 The shares ranged from 3\% for Świętokrzyskie to $13,5 \%$ for Mazovia. Only in three regions did their shares exceed $9 \%$, and only six regions had a share higher than $6 \%$. 
of Łódź, operating since 2014). The appearance of these new carriers has facilitated the reopening of some lines which had previously been closed, in particular in Lower Silesia.

As of today (mid-2016), two regional governments, Mazovia and Silesia, buy public rail services exclusively from their own operators. Given the important role of railway transport in these regions, Koleje Mazowieckie and Koleje Ślaskie transport more passengers than PR in the rest of the country. The regions of Lower Silesia, Wielkopolska, Małopolska and Łódzkie share their public contracts between their own operators and PR - yet the market share of the later is dropping and the regional authorities declare that they intend to eventually abandon cooperation with the incumbent company.

The PR incumbent company remains responsible for the provision of regional rail services in other regions. The only and important exception is found in the Kujawsko-Pomorskie Region where DB-owned Arriva started operations in 2007 by winning a tender for non-electrified sections (a 3-year contract). This tender showed Polish regional authorities how important savings on subsidies in public services can be when competition takes place. The Arriva offer stood at PLN 12.93 per train km while PR offered 18.36 per train $\mathrm{km}$. After three years, Arriva was the successful bidder again (PLN 17.99 v. PLN 35.48), yet this time obtaining the concession for a 10-year period (2010-2020) (Arriva, 2013, p. 12). Arriva also managed to win a 3-year contract (2013-2015) for a set of electrified lines in the Kujawsko-Pomorskie Region.

Arriva is the only market player in Poland that is independent from public service organizers (i.e. that is not owned or co-owned by regional authorities). However, due to the local nature of its activities, Arriva's market shares are almost negligible (what can be seen on Figure 1). Ironically, creating their own railways appears to regions as a safer and more comfortable weapon against

Figure 1. Market shares of operators active on the market for regional rail transport in Poland (\% of passenger-km, 2015)

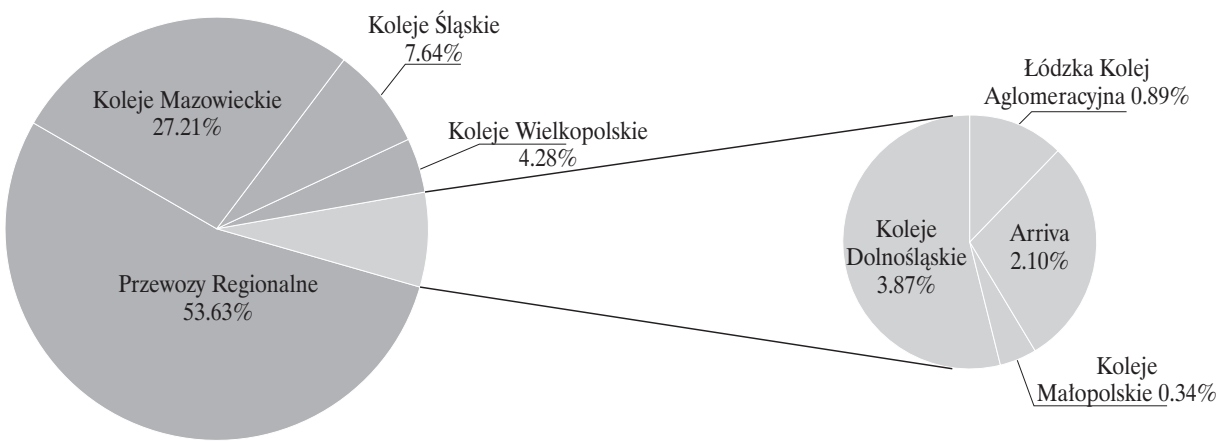

Source: authors' own calculations based on UTK data. 
the monopoly of PR than putting services out to tender. That is, region-owned railways are, paradoxically, a local response to the underdevelopment of the market for public rail services. Monopolistic by its very nature, their services are almost as expensive as the services offered by the incumbent PR operator. The advantage of having its own rail operator is, however, financial stability and transparency, and responsiveness to the owner's needs ${ }^{15}$. Clearly, regions prefer quite expensive tranquillity over the uncertainty associated with the promises of competitive bidding on the underdeveloped market.

The Polish government finally recognized the fiasco of the idea to "devolute" PKP PR. The controlling interest in the company has been taken over by a governmental agency in 2015 and its restructuring has been announced. The immediate result of this is, however, rather unfavourable. PR became again a sort of a "national carrier" and the government began to care about it again: regional authorities cooperating with PR have been kindly asked to sign longer-than-before contracts with PR in order to secure some financial stability for the company, and so they have. Accordingly, Kujawsko-Pomorskie Region has not re-tendered its electrified lines after the concession to Arriva expired in 2015. The new concession has been directly awarded to the governmentowned PR. Figure 1 shows the market shares of operators active in the Polish market of regional rail public services by the end of 2015 .

\section{The Czech Republic}

The existing model of regional railway organization in the Czech Republic is certainly a result of the aforementioned historical developments. It has to be described as rather stable, both in the institutional and spatial sense. However, the fact cannot be sufficiently stressed that it has taken its shape in the aftermath of the transformation of 1989 and the dissolution of Czechoslovakia in 1993. The first reforms of the ČSD were launched in 1991 in accordance with the Program Strategy of Rail Transport till 1995 in the circumstances of the economic reform (Programová strategie železniční dopravy do roku 1995 v podminkách ekonomické reformy of 8 May 1991) and the Principles of National Transport Policy (Zásady státní dopravní politiky of 26 September 1991). As a consequence of the dissolution of the common state, new national railway companies, České dráhy (ČD) in the Czech Republic and Železnice Slovenskej republiki (ŽSR) in Slovakia, were created in 1993. The first reforms of the newly formed CD company were launched in 2002. They were meant to adjust

15 Accordingly, regional governments are typically eager to sign long-term contracts with them - e.g. Koleje Śląskie has a 10-year contract with Silesia (2015-2025), Koleje Dolnośląskie has a 8-year contract with Lower-Silesia (2015-2022). 
the organizational structure of the Czech railways to European guidelines, which foresaw a division between infrastructure managers and operators. As a result, two new companies were created in the Czech Republic: České dráhy (ČD) as a passenger and freight operator ${ }^{16}$ and Správa železniční dopravní cesty (SŽDC) as an infrastructure manager ${ }^{17}$. Hence, the new operator retained the name of the former vertically integrated Czech Railways.

It should be emphasized that a clear distinction between national and regional railway lines existed already in the first official documents published in the 1990s. The Railway Law of 1994 defines the latter as lines of local or regional importance, which are used to provide public services and which are connected with a national or another regional line ${ }^{18}$. Moreover, 128 regional lines were formally excluded from the national network in 1995 . This decision was at the beginning purely bureaucratic, although the original plan was to prepare the privatization of these lines (Zlinský, 2012). Yet after regional governments were burdened with the responsibility for regional railway services in 2010, this issue gained in importance ${ }^{19}$.

One of the most important documents for the present organizational model of regional railways in the Czech Republic is the Law about Public Services in Passenger Transport from $2010^{20}$. According to this law, it is the communities and regions which are responsible for organizing and financing regional transport on their territories ${ }^{21}$. Interregional connections, by contrast, are an area of responsibility of the state. However, it should be emphasized that the national government subsidizes the regions in financing regional rail transport. Based on an agreement which was signed by the Prime Minister, the Ministry of Transport and heads of the regions in 2009, 2.649 billion Czech crowns, CZK (50.4283 billion EUR) should be allocated every year between 2009 to 2019 to the regional governments for this purpose $^{22}$. Thanks to this decision,

16 The division into a passenger carrier ( $\check{C} \mathrm{D})$ and a freight carrier ( $\check{C} \mathrm{D}$ Cargo) took place only in 2007.

17 Předpis č. 77/2002 Sb., Zákon o akciové společnosti České dráhy, státní organizaci Správa železnični dopravní cesty a o změně zákona č. 266/1994 Sb., o dráhách, ve znění pozdějšich předpisü, a zákona č. 77/1997 Sb., o státním podniku, ve znění pozdějších předpisü.

18 Zákon o dráhách č. 266/1994 ze dne 14. prosince 1994.

19 At present (2016), 161 lines are classified as regional lines. This status makes it possible to reduce the costs of service as a train-kilometre on regional lines costs 5.32 crowns (0.1968 EUR) plus 29.20 crowns (1.0802 EUR) for 1,000 gross tonne-kilometres whereas on national lines the costs goes up to 6.28 crowns (0.2323 EUR) and 34.45 crowns (1.2745 EUR) respectively.

20 Předpis č. 194/2010 Sb. Zákon o veřejných službách v přepravě cestujících a o změně dalšich zákonů.

21 Actually, regional governments were saddled with the responsibility for these issues already in 2005.

${ }^{22}$ Memorandum o zajištění stabilního financování dopravní obslužnosti. veřejnou regionální železniční osobni dopravou of 2009. 
it is possible to provide a stable regional transport offer. In fact, over the last two decades, the Czech railways have managed to maintain a well-developed system of regional and local lines, which has been used quite intensely in terms of trains and passengers.

However, stability does not mean the lack of any change. An important novelty, foreseen already in the 1990s, appeared: the entry of new carriers that are independent from the state. Open access competition was introduced in 2011 in inter-regional connections on the Czech Republic's main trunk line from Prague to Ostrava. Apart from ČD, two private companies offer their services on that line.

Regional governments have started to open their railway markets as well. These attempts are usually the result of the fact that regional governments struggle to obtain information from the incumbent national railway company about the actual train costs on given lines. Hence, they question whether the demanded subsidy is not in fact much higher than the real costs incurred by the incumbent. This problem stimulates the decision-makers to take into consideration an alternative solution, that is, to launch a tender for public railway services. This has been the case on the line Karlovy Vary - Mariánské Lázně $(53 \mathrm{~km})$ in Western Bohemia in 2005. Costs according to the demands of the ČD and the winner of the tender - a private company called Viamont (present name: GW Train Regio) as well as ticket prices are compared in Table 1.

Table 1. Comparison of costs of services on the regional line Karlovy Vary - Mariánské Lázně

\begin{tabular}{|l|c|c|}
\hline & ČD & Viamont / GW Train Regio \\
\hline Costs of train-kilometre in 2005 [CZK/EUR] & 80.41 & 64.63 \\
& 2.7528 & 2.2126 \\
\hline One way ticket price for 53 km distance in 2016 & 80.00 & 66.00 \\
[CZK/EUR] & 2.9597 & 2.4417 \\
\hline
\end{tabular}

CZK to EUR exchange rate is given for 2005 and 2016 respectively.

Source: authors' own elaboration on the basis of: Bocková, 2005; www.cd.cz (16.07.2016); www. gwtr.cz (16.07.2016).

The most important result of the tender has thus been the decrease by $20 \%$ in the cost of the train-kilometre. Furthermore, also the price of the ticket in the GW Train Regio trains is about $20 \%$ lower than in those of the Čㅁ․ At present, GW Train Regio is the most important regional railway carrier apart from the ČD. It operates five local lines in the Ore Mountains and the Sudets: Karlovy Vary - Mariánské Lázně, Sokolov - Klingenthal (Germany),

${ }^{23}$ However, the ČD offers a very well-developed discount system (e.g. for groups), one-day network tickets as well as loyalty programmes. 
Trutnov - Svoboda nad Úpou, Trutnov - Královec - Jelenia Góra (Poland) and Milotice nad Opavou - Vrbno pod Pradědem ${ }^{24}$.

Another reason for the appearance of new carriers has been the fact that the state-owned $\check{C} D$ was reluctant to reconstruct some of the local lines damaged in the 1997 flood, while local governments were interested in maintaining their train services. This applies to two lines: Milotice nad Opavou - Vrbno pod Pradědem and Šumperk - Kouty nad Desnou/Sobotín (all in the Sudets). The service on the former line has been taken over by Viamont (GW Train Regio); the latter was at first operated by the construction firm which had rebuilt the train infrastructure and later taken over by Connex (later Arriva). Paradoxically, after the electrification of 2015, the regional government decided to entrust the service to the ČD since - unlike Arriva or GW Train Regio - it owned electric rolling stock. Since then Arriva has been active only on a short branch line to Sobotín (Jirásek, 2016).

A small, but interesting element of the Czech railway market lies is regional train services which are organized at the sole risk of the provider. So far, only Arriva has entered this sector. After having operated suburban trains on the Kralupy nad Vltavou - Prague - Benešov line for three months in 2012, Arriva decided to come back in 2016 with connections from Prague to Benešov and weekend trains to Trenčín in Slovakia ${ }^{25}$.

Still, the scale of the opening of the Czech railway market can be still described as small (Figure 2). It does not seem that the monopolistic position of the $\check{C} D$ is going to change any time soon. This is because in 2009 - just before the new Law on Public Services in Passenger Transport was passed -

Figure 2. Market shares of operators active in passenger rail transport in the Czech Republic (\% of passenger-km, 2015)

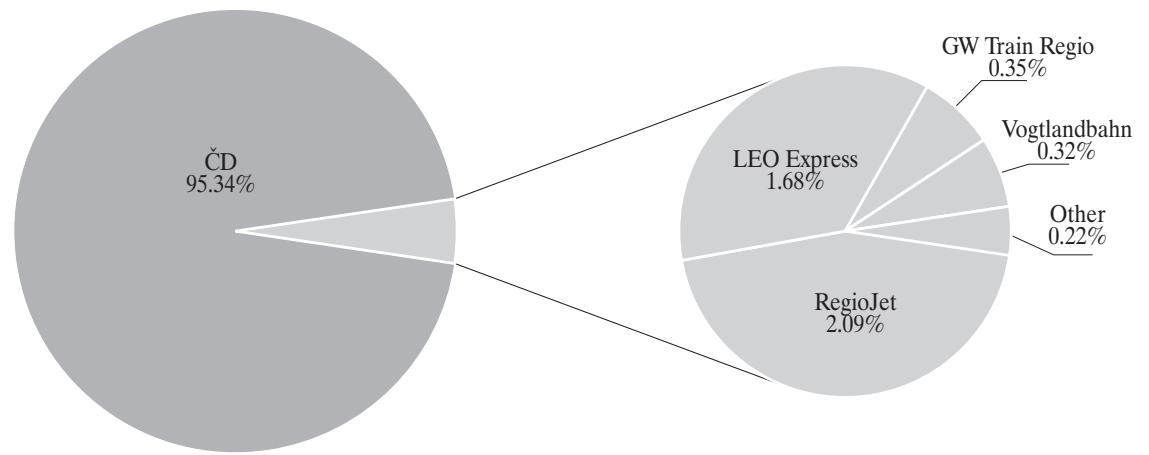

Source: authors' own elaboration based on SŽDC data (Výroční zpráva, 2014).

\footnotetext{
24 www.gwtr.cz (06.07.2016).

25 www.arriva-vlaky.cz (16.07.2016).
} 
all 14 regions decided to sign a contract with the ČD which foresees that the national carrier will be operating regional lines till 2019 with a prolonging option for the next five years (Tomeš, Kvizda, Nigrin and Seidenglanz, 2014, p. 275). This means the ČD were given 150 billion CZK (5.8754 billion EUR) without the use of a tender (Sůra, 2009).

In conclusion, the Czech model of regional railway organization can be described as a stable and conservative one. The stability of the well-developed network of regional and local railway lines, which has not changed significantly after it was constructed at the end of the $19^{\text {th }}$ century, is certainly particular. In fact, the Czech Republic is one of the very few European countries where almost the entire railway system, as it was created over 100 years ago, is still in operation. The adjective "conservative" stands not only for the maintenance of the old spatial structures, however, but also for the predominance of the national railway company in the service.

\section{Slovakia}

The model of organizing the passenger railway system in Slovakia was up to 1993 the same as in the Czech Republic as they both formed one country. After the dissolution of Czechoslovakia, a new national company was formed - the ŽSR. However, no structural modifications were made to the incumbent till 2001 when the ŽSR was divided into: the infrastructure manager (ŽSR) and the carrier (ZSSK). Three years later, the ZSSK was separated once gain into a passenger and a freight transport company - ZSSK and ZSSK Cargo respectively ${ }^{26}$.

The institutional aspect of the passenger railway sector in Slovakia can be described as very conservative because it is still the national government which decides and finances the entire sector - including regional connections (Nemeth, 2012, p. 60). Regional bus transport, by contrast, is in the competence of regional governments (Gnap and Poliak, 2005). Another reason to call the Slovak passenger railway system - and especially its regional part - conservative is its particularly low liberalization level. In fact, apart from open access competition in international long-distance connections to the Czech Republic (which is, de facto, the result of prolonging domestic Czech services to Žilina, Košice and Prešov) and the weekend Arriva train from Prague to Trenčín (see the section about the Czech Republic above), activities of new carriers, which are independent from the ZSSK, are limited to one line only. This sole example of regional railway market opening is the line from Bratislava to Komárno (100 km long).

26 Uznesenie vlády SR č.662/2004 zo dřa 7.7.2004. 
In 2011, the Ministry of Transport, Construction and Regional Development entrusted the company RegioJet (the aforementioned new entrant) with the provision of the service on this line for the next nine years. The decision to commission a carrier other than the ZSSK with railway services without any tender was treated as an experiment in order to test whether the new company was able to attract new passengers. The Ministry of Transport, Construction and Regional Development had the intention to apply to the Ministry of Finances for an increase in the subsidy to railways, if more people switched from individual to rail transport (Petrák, 2012). However, the argument was also present that the appearance of a new carrier would result in a decrease of the subsidy. In fact, the costs demanded by RegioJet turned out to be about $16 \%$ lower than those paid to the ZSSK (Table 2).

Table 2. Comparison of costs of services on the regional line Bratislava - Komárno

\begin{tabular}{|l|c|c|}
\hline & ZSSK & RegioJet \\
\hline Costs of train-kilometre in 2011 [Euro] & 6.60 & 5.70 \\
\hline Subsidy from the national government [million Euro] & 8.40 & 7.10 \\
\hline One way ticket price for 100 km distance in 2016 [Euro] & 5.25 & $5.25^{*}$ \\
\hline
\end{tabular}

* there is a special offer for tickets from Bratislava to Komárno. The tickets can be purchased in customer centres only and cost 4.50 instead of 5.25 Euro.

Source: authors' own elaboration on the basis of: Kováč, 2011; Valček, 2011; www.regiojet.sk (17.07.2016) and www.slovakrail.sk (17.07.2016).

The introduction of the new carrier was connected with the modernization of the line Bratislava - Komárno. The result of that modernization as well as the purchase of new diesel units, replacing trains made up from heavy locomotives and carriages, cut travel time from about $2 \mathrm{~h} 20 \mathrm{~m}-2 \mathrm{~h} 30 \mathrm{~m}$ to $2 \mathrm{~h} 8 \mathrm{~m}$. Moreover, the frequency of trains increased from 10 to 12 pairs of trains between Bratislava and Komárno. The reaction of passengers was quick. In four years of RegioJet service, the number of passengers increased by $300 \%$ (RegioJet, 2016).

The stability of the organizational aspect of Slovak railways does not apply to its spatial structure. Unlike in the Czech Republic, a vast regression of the passenger network can be observed after 2003. The decision was made at that point in time to close 21 sections for passenger trains (total length of $482 \mathrm{~km}$ ) - that is about $13 \%$ of the entire Slovak network. This was part of a more complex austerity programme including the cancellation of over 100 other trains and employee redundancy (Gulík, 2013). Although after largescale protests nine lines were reopened after a few months, most of the closed sections were never reopened. 
To sum up, Slovakia combines a very conservative organizational scheme of passenger railways, where the state plays the predominant role as the sole service purchaser and the owner of the de facto monopolistic national company, with a large-scale reduction of its railway network. There might be a link between these two elements because the lack of influence of the regional and local governments on railways was probably a factor which facilitated the closure of so many lines. National governments are often not sufficiently informed about the needs of local people. A question arises here whether this particular organizational model is able to continue. The experiment to open one regional line to a carrier independent form the ZSSK might be the first step towards liberalization on a larger scale.

\section{Conclusions}

Poland, the Czech Republic and Slovakia provide three different models of regional railway organization. The historical, socio-economic and spatial factors of railway network development in the three neighbouring CentralEuropean countries have been diverse. Whereas the present Czech Republic has always been characterised by a well-developed system of local and regional railways, which served a dense network of towns and industrial plants, Poland had to suffer the consequences of the partition of its territory between three different countries until 1918. Slovakia, by contrast, developed its railways as part of the Kingdom of Hungary. The pre-war and communist Poland and Czechoslovakia were characterised by different railway development as well. Their differences did not disappear even after 1945 under the common rule of communism. Although the transport demands of Soviet-style heavy industry were similar, the scale of new infrastructural investments was different in the already highly industrialized Czechoslovakia and still predominantly rural Poland. Despite the priority of freight-oriented railway investments in both countries, Czechoslovak railways managed to maintain the tradition of rational and economic organisation of regional services, not least because of a largescale programme of railcar manufacturing - a feature absent in Poland.

These factors set the stage for the railway development schemes after the transformation. In fact, whereas the Czech Republic has maintained a particularly dense network of regional and local railways, Poland has faced a vast-scale railway regression (Figure $3^{27}$ ). The general role of railways in the transport

27 The data in fig. 3 present the total length of all railway lines in the three analysed countries, hence they include also the sections on which only freight trains were in operation. This is why they do not reflect very well the changes in the passenger railway network, in particular in Slovakia. 
systems, reflected in their "passenger-distance" performance (Figure 4), has been generally in line with network development. The position of Slovakia can be described as an intermediate one, with network changes more similar to the Czech Republic and passenger-distance reduction that resembles Poland.

The organisational models that emerged in the three analysed countries also differ significantly from each other. Interestingly, the initial development after the transformation had begun was quite similar: the first transport strategies and new laws on railways were introduced in the 1990s, and the first modest steps towards market liberalisation were made about 2001. The main goal of the reforms of the early 2000s was to adjust the organizational structures of railways to European guidelines that foresaw a division between infrastructure managers and service operators. However, the actual models which have emerged in the aftermath of these reforms had different results.

Figure 3. Length of railway lines in Poland, the Czech Republic and Slovakia in 1990-2013 (km)

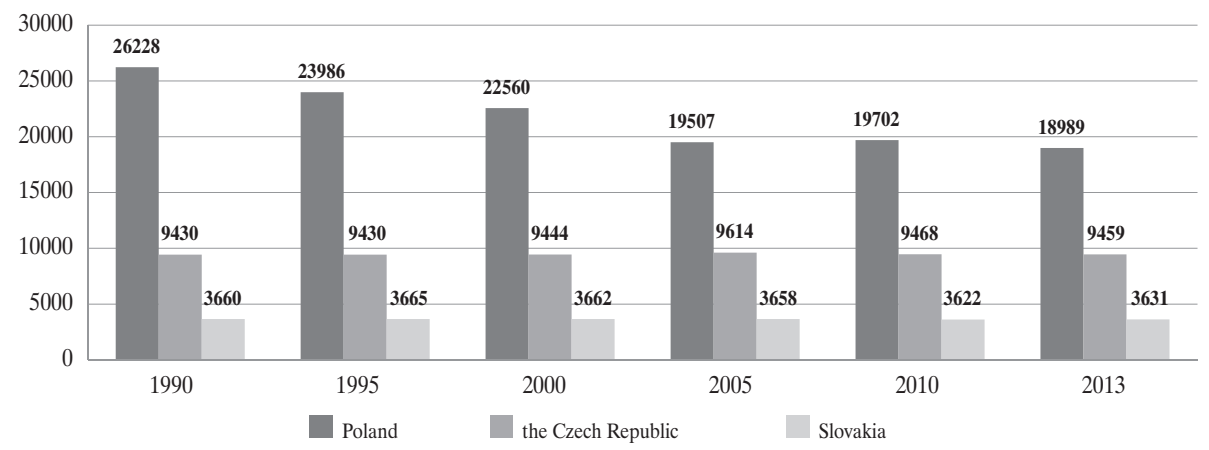

Source: authors' own elaboration based on Eurostat data.

Figure 4. Transport performance of railways in Poland, the Czech Republic and Slovakia in 1990-2014 (billions of passenger-km)

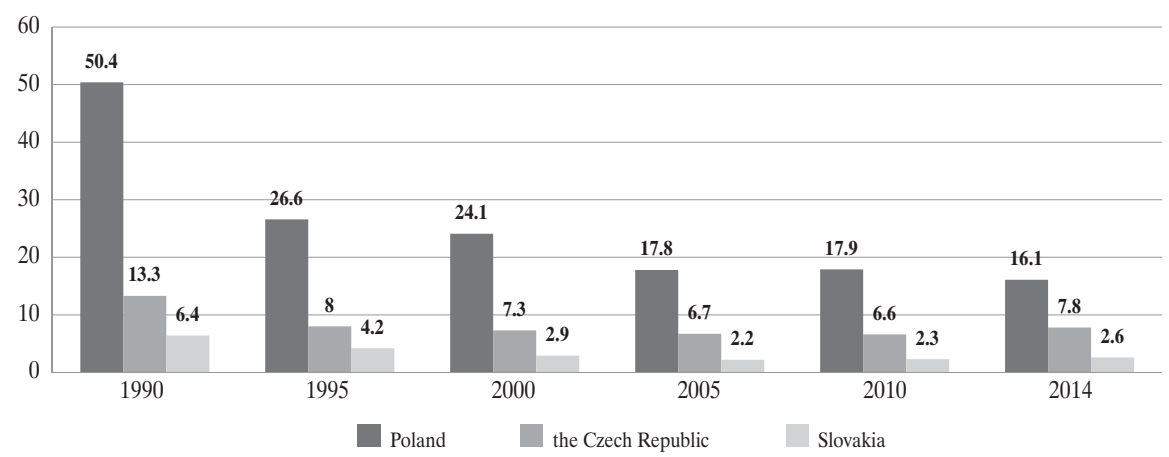

Source: authors' own elaboration based on Eurostat data. 
Poland has been the only country which has decided to create a separate operator to be responsible solely for regional transport - PKP PR. Although Polish regional governments were obliged to organize regional railway services as early as 2000, the subsidy for regional transport was carried out in the first three years exclusively by means of a state budget grant, which turned out to be much lower than previously promised. The far-reaching consequences of this situation included a large-scale network reduction and acute financial crisis of the PKP PR incumbent. The subsequent bizarre development of the regional railways organization toward a fictional "competition for the market" model was quickly followed by the complete withdrawal of the state from regional transport organization and the "devolution" of PKP PR. However, the incumbent company was still perceived as "alien". In order to shield themselves from the incumbent's opportunistic behaviour, several regional governments decided to create their own regional railway operators and to award public contracts to them "in-house". Thus, creating local monopolies as a tool to combat the monopolistic practices of a national incumbent is emblematic to the Polish model. The recent decision of the government to make the incumbent into a national operator once again, adds to a rather chaotic sequence of domestic experiments.

The Czech and Slovak models, by contrast, are much more traditional and stable with the predominant role of the incumbent $\check{C} \mathrm{D}$ and $\check{Z} \mathrm{SR}$ respectively, which are still in the hands of the state and hold positions of national operators. The Slovak model can be described as particularly conservative. Apart from some open access Czech companies which are active on the long-distance lines to Prague, only one external carrier is present in Slovakia. Moreover, the organization and financing of regional railway services remains the responsibility of the national government. While the scale of market opening in the Czech Republic is larger than in Slovakia, if compared with some Western-European countries it can be described as very small still. The role of the incumbent is absolutely predominant and it does not seem that this is going to change any time soon as all Czech regions have decided to sign longterm direct contracts with ČD.

A question arises whether, and for how long, the analysed CentralEuropean countries are able to maintain their own - quite particular and varied - models of regional railway organization. Only time will tell. Without any doubts, however, the postponed prospects of the full introduction of the Fourth Railway Package will not induce governments to any decisive actions ${ }^{28}$.

28 The Fourth Railway Package is a set of legislative measures aimed at creating the single European railway market. One of its features is to introduce obligatory competition for public service contracts in the railway sector. As of the time of writing of this paper, it has been negotiated that competitive bidding for public contracts would become the norm from 2023. However, any contract awarded directly before 2023 would need to expire only in 2033. 


\section{Literature}

Arriva (2013). Liberalisation and competition in the European regional rail market. Retrieved from: http:/www.arriva.co.uk/ /media/Files/A/Arriva-Corporate-V2/pressrelease/2013/29-10-2013-2.pdf (01.10.2016).

Basiewicz, T., Łyżwa, J. and Modras, K. (1977). Centralna Magistrala Kolejowa ŚląskWarszawa. Warszawa: Wydawnictwa Komunikacji i Łączności.

Bittner, J., Křenek, J., Skála, B. and Šrámek, M. (2010). Malý atlas lokomotiv 2011. Praha: Gradis Bohemia.

Bocková, A. (2005). Krajští radní schválili nového dopravce na železniční trati Karlovy Vary - Mariánské Lázně. Krajské listy, Karlovarský kraj, http://www.kr-karlovarsky.cz/ krajske_listy/Stranky/251005_KV-ML.aspx (01.10.2016).

Finger, M. and Messulam, P. (eds.) (2015). Rail Economics, Policy and Regulation in Europe. Cheltenham-Northampton: Edward Elgar Publishing.

Gnap, J. and Poliak, M. (2005). Financovanie verejnej hromadnej osobnej dopravy. Doprava a spoje 1, http://fpedas.uniza.sk/dopravaaspoje (01.10.2016).

Gómez-Ibáñez, J.A. (2003). Regulating Infrastructure. Monopoly, Contracts, and Discretion. Cambridge-London: Harvard University Press.

Gulík, J. (2013). 2003-2013, www.vlaky.net (01.10.2016).

Jarząbek, M. (2012). Społeczny odbiór kolei. In: D. Keller (ed.), Dzieje kolei w Polsce. Rybnik: Eurosprinter, Muzeum w Rybniku, 58-59.

Jirásek, J. (2016). Arriva skončí na trati do Kout nad Desnou. Kraj si vybral České dráhy, http://www.firenet.cz/specialy/118-lokalka-tour/2556-arriva-skonci-na-trati-do-kout-naddesnou-kraj-si-vybral-ceske-drahy (21.05.2016).

Komusiński, Sz. (2010). Przekształcenia przestrzenne sieci pasażerskiego transportu kolejowego w Polsce w latach 1988-2008. Prace Komisji Geografii Komunikacji PTG, XVIII.

Kováč, J. (2011). RegioJet na Slovensku nasadí jednotky Bombardier Talent, http://www. zelpage.cz/zpravy/7980 (01.10.2016).

Koziarski, S. (1993). Sieć kolejowa Polski w latach 1918-1992. Opole: Państwowy Instytut Naukowy Instytut Śląski w Opolu.

Kubáček, J. (2007). Dejiny železníc na území Slovenska. Bratislava: Železnice Slovenskej Republiky.

Nemeth, F. (2012). Strategická pozícia a výkonnosť železničných podnikov v SR. Trendy v podnikání - Business Trends, 4, 57-64.

Petrák, J. (2012). RegioJet představil nabídku pro osobní vlaky Bratislava - Komárno, http:// www.zelpage.cz/zpravy/8370 (01.10.2016).

RegioJet (2016). Intenzivne riešime preplnenost' súprav, https://www.regiojet.sk/nase-trasy/ bratislava-komarno/plne-vlaky (17.07.2016).

Schreier, P. (2010). Naše dráhy ve 20. století. Pohledy do železniční historie. Praha: Mladá fronta.

Sůra, J. (2009). Kraje daji drahám 150 miliard bez soutěže, http://ekonomika.idnes.cz/ kraje-daji-draham-150-miliard-bez-souteze-d92-/ekonomika.aspx?c=A091110_214303 ekonomika_mmb (01.10.2016).

Taylor, Z. (2007). Rozwój i regres sieci kolejowej w Polsce. Warszawa: Instytut Geografii i Przestrzennego Zagospodarowania im. S. Leszczyckiego PAN. 
Tomeš, Z., Kvizda, M., Nigrin, T. and Seidenglanz, D. (2014). Competition in the railway passenger market in the Czech Republic. Research in Transportation Economics, 48, 270-276.

Valček, A. (2011). Ludia si vyskúšali súkromný vlak od RegioJetu, http://ekonomika.sme. sk/c/5870379/ludia-si-vyskusali-sukromny-vlak-od-regiojetu.html (01.10. 2016).

Zlinský, Z. (2012). Lokálky státem nemilované, http://www.vlaky.net/zeleznice/spravy/4410Lokalky-statem-nemilovane/, (01.10.2016). 